\title{
Katherine Mansfield and Empire
}

\author{
Janet M. Wilson
}

ABSTRACT

As modernity, and by implication modernism, is increasingly interpreted as a global and transnational phenomenon, functioning through multiple interactions across social and geographical locations, and as empire is likewise often perceived as globally constituted, part of a world system, Mansfield's dual affiliations to her New Zealand society of origin and the European world where she pursued her art have come under new scrutiny. This chapter draws on these expanded critical frameworks, seeing Mansfield as a colonial-metropolitan writer, who masked her colonial 'otherness' as British to enable an anonymous multi-positionality. It argues that her satire of German imperial values in stories published in In a German Pension (1911) belies an interior subjective space in which she cultivated in her art a colonial counter-imaginary focused on issues of gender and women's place. Her chiastic crossover between imperial and colonial sensibilities, and enfolding and overlapping of their different geographies and temporalities, informs a reading of two early New Zealand 'outback' stories of savagery, "The Woman at the Store" (1912) and "Millie" (1913). Gaps and silences in these narratives indicate untouched areas of the colonial experience she would plunder in later stories and anticipate the postcolonial critiques of subsequent writers.

Biography

Janet M. Wilson is Professor of English and Postcolonial Studies at the University of Northampton. She recently co-edited with Aimee Gasston and Gerri Kimber the collection, Katherine Mansfield: New Directions (2020), and has just published the edition, The General and the Nightingale: Dan Davin's War Stories (2020). She is vice-chair of the Katherine Mansfield Society, co-editor of the Journal of Postcolonial Writing and series editor of Ibidem-Verlag's Studies in World Literature.

The role of empire and European imperialism in relation to Katherine Mansfield's colonial upbringing in New Zealand and her adult life in Europe where she pursued her art is crucial for understanding her place as one of the major figures of literary modernism who, at the beginning of the twentieth century, towered over both modernism's colonial and metropolitan forms. These geopolitical formations have inspired the key perception of Mansfield as a colonial-metropolitan modernist writer with dual affiliations to her provincial society of origin and the metropolitan homeland of England, which enabled her to reshape and extend the filiative ties of empire into dynamic relations cutting across or challenging hierarchies of 
gender, ethnicity, and class. ${ }^{1}$ Indeed, it can be argued that her elusive, ambivalent responses to the ideology of imperialism might be explained by her colonial orientation which encouraged her to adopt a chiastic cross-over position between both sensibilities, colonial and imperial, overlapping their different geographies and temporalities, and looking both ways to forge a distinctive aesthetic irony. This includes hybrid discourses anticipatory of postcolonial resistances and alternative subjectivities ${ }^{2}$ as in the citation of new locations of habitation and consciousness and signifiers of race in stories like "How Pearl Button was Kidnapped" and "Je ne parle pas français," and in the anti-colonial satire of "The Daughters of the Late Colonel." 3

Recent scholarship has offered expanded frameworks for analyzing modernism and empire, seeing them as linked to form a compatible "discursive base/superstructure dyad," further challenging the Manichean binaries of provincial and metropolitan, center and periphery. ${ }^{4}$ Perspectives of empire as dominated by global structures of power leading to its legacy of power imbalance_- “informal” imperialism consisting of financial and commercial expansion, anticolonial resistance movements as alternative forces of authority-inform new interpretations of Mansfield's place in literary history. ${ }^{5}$ Contemporary conditions of mobility and rootlessness that challenge the assimilationist ideologies of the nation-state point to the expansiveness of the global empire-building project: its diverse and dispersed networks and rhizomatic, lateral trajectories that cross empire's boundaries and overlap with the back and forth center-colony movement. ${ }^{6}$ Elleke Boehmer argues in favor of a more globally reconstituted model of empire than the empire-colonial configuration as "multiply mediated by diversified exchanges between nations on the margins,"7 another perception that urges reconsideration of Mansfield as a mobile world traveler whose global modernist orientation encouraged a chiastic orientation towards space and time, history and location. The centerperiphery binary was also superseded in the political workings of the imperial world system 
which, as Frederic Jameson and others note, consisted of a rivalry between nation states that masked the exploitation of colonial territories; this is detectable in the veiled animosities of Herr Rat in Mansfield's story, "Germans at Meat". ${ }^{8}$ Mansfield may also have been aware that Britain and its empire were being provincialized due to the rise of continental world powers, Russia and the USA, another indication of imperialism's shifting dynamics prior to World War One. To critic Simon During, these broader horizons for locating Mansfield's work give her the distinction of being a world literature writer. ${ }^{9}$

Modernism is likewise increasingly perceived as a transnational phenomenon, not just the product of Anglo-American culture but as functioning through multiple zones of crossborder interactivity in diverse imperial and colonial locations, as a result of the global contexts that shaped its emergence. Modernism's uneven engagement with otherness and difference, according to Boehmer, with "a modernist-other interface or contact zone," means that it may be "more consistently read as situated and conducted in the perspective of Empire" than as a distinctive aesthetic movement and constellation of European, metropolitan literature. ${ }^{10}$ Narratives from colonized nations when examined from these angles suggest modernism's diffusion and venacularization, effected through the globalized interface of colony and empire: Declan Kiberd has written of James Joyce's challenge to the norms of Irish nationalism in his interpretation of British imperialism and the project of Euromodernism, including the use of the traditions and linguistic terms of the Celtic twilight in tension with international modernism; Jane Stafford and Mark Williams see Mansfield's early composite style as blending formal innovation from Wilde and the symbolists with the indigenous idioms and terms of Maoriland writing in a transformed version called colonial modernism. ${ }^{11}$

Mansfield's arrival in London in 1908 coincided with the era of high Empire (18701918), which was to end with the Great War, a world-threatening crisis that ultimately 
undermined the power of imperialism. Her modernist experimentation and critique were informed by cultural and intellectual currents associated with the two avant-garde journals in which she first published: A. R. Orage's The New Age, and then John Middleton Murry's Rhythm. Both preached new aesthetic and political gospels and the latter, with its manifesto adapted from John Synge, “"Before art can be human it must learn to be brutal," was of seminal importance for her evolving modernism such as in her colonial stories about the white settler negotiation of the imperial legacy. ${ }^{12}$ But it was the profound shock of the First World War, mainly due to the tragic death of her brother, that elicited her most highlycharged critical response. The war's wide-spread devastation changed everything, transforming the age, as she wrote to John Middleton Murry: "I feel in the profoundest sense nothing can ever be the same, that as artists we are traitors if we feel otherwise."13 Her late story, "The Fly" (1922), exposes the unsustainability of imperial myths of sacrifice and glory that mobilized a generation of young men to go to their deaths.

As a colonial outsider from the furthest margin of empire who relocated in metropolitan England, Mansfield's position from the outset was compromised by her complicity with imperial values and power structures. Accustomed from her privileged background to wealth and freedom, her transnational mobility as a traveler between England and European metropolitan destinations meant that she was often taken for English, enabling her to enact a metropolitan identity that concealed her colonial New Zealand one; she would have experienced empire as a multiply-constructed entity in interaction with its colonies and effecting cross-border exchanges between nations on its boundaries, as well as those beyond them. Her apparent anonymity and national invisibility, also enabled by her role-playing and name-changing, explain the multi-locatedness of many stories: permeable national and imperial borders underpin the images of cultural foreignness and constructions of national belonging and alienation in those from In a German Pension (1911) and later ones like "A 
Dill Pickle" (1917) and "Honeymoon" (1922), and her collaborations in translation projects with S. S. Koteliansky constitute further explorations in cultural and linguistic difference. Artistically, therefore, Mansfield was globally oriented and moved beyond the perimeters of European empires to discover the divisions between the west and non-west as sites of creative possibility. In particular is her passion for Russian writing and the transformative effect upon her early work of Chekhov, most famously seen in the story, "The-Child-Who-Was-Tired," while her translations from Russian into English of golden age literature by masters like Dostoevsky and Tolstoy also undoubtedly shaped her writing. ${ }^{14}$ Mansfield's diverse journeys in Europe and her discovery of its cultures, therefore, took her constantly beyond the binary framework of empire and colony at the same time as her colonial worldview was being reshaped by memory, longing, and the past of her New Zealand childhood.

Using a chronological-biographical approach to the shifting frameworks of colony and empire in her work, and in order to consider her as a writer who negotiates various resistant, complicit, or oblique responses to imperial assumptions, this chapter will compare the European stories in Mansfield's earliest collection, In a German Pension, with two New Zealand "regional" stories, "Woman at the Store" (1912) and "Millie" (1913). It argues that the ideology of empire as articulated in the collection through the discourses of nation, race, and gender is radically revisited and rewritten from the colonial perspectives of the latter stories in ways consonant with Mansfield's fluid manipulation of both positions; and furthermore their narrative ellipses and silences hint at unrecorded experiences that anticipate later postcolonial representations that "subtend yet transcend the colonial encounter". ${ }^{15}$

\section{In a German Pension}

The European stories published in In a German Pension provide a reimagining of self-other relationships and alternative cultural representations to those found in the stories and sketches 
that Mansfield wrote before she left New Zealand which synthesize the idioms, motifs, and Polynesian myths of "Maoriland" writing with a Wildean, late-Victorian literary aesthetics. Focused on her stay at the Pension Müller in the little spa town of Bad Wörishofen ${ }^{16}$ in Bavaria where she lived for six months in 1909, the stories conceal the chaotic upheaval in her life then. Abandoned by her lover, the musician Garnet Trowell, by whom she was pregnant, and having briefly married the singing teacher, George Bowden, on the rebound on 2 March 1909, she was removed in May from this difficult situation by her mother, who had arrived from New Zealand and accompanied her to the spa town for a health "cure." ${ }^{17}$ Written in a state of isolation, the stories suggest she was grappling with an overwhelmingly strange and foreign environment. She wrote to Garnet Trowell in June 1909, not long after she arrived, of her psychic dislocation and visceral bodily suffering, possibly as the result of the miscarriage she suffered there:

To be alone all day, ill, in a house whose every sound seems foreign to you — and to feel a terrible confusion in your body which affects you mentally, suddenly pictures for you detestable incidents — revolting personalities — which you only shake off — to find recurring again as the pain seems to diminish $\&$ grow worse. ${ }^{18}$

Mansfield's separation from her provincial colonial beginnings and metropolitan influences with their familiarizing and estranging perspectives marked her stay in Wörishofen. In the stories she satirizes and impersonates "revolting personalities" and "detestable incidents" at the pension through a comic-critical optic, introducing unfamiliar character types and diverse self-representations. Underlying her mocking, biting satire is a probing investigation of otherness, an alterity that includes herself. Estranged from all that was familiar, she developed a mode of apartness as she had done in New Zealand before she left by the 
cultivation of a literary persona; this may have been affected by an alienating, depersonalizing paralysis, described as "this coldness— physical, mental—heart coldness— hand coldness-soul coldness." 19

Seven out of the thirteen stories feature a first-person narrator who exploits the communicative gaps caused by cross-linguistic and cross-cultural contact with the Germans in the Pension. The narrator, a persona of Mansfield, represents herself as a femme seule of mysterious identity, with little apparent reason for taking the cure or "bad." She consistently "passes" as English and refuses to acknowledge her national origin, reinforcing a common misunderstanding among the Germans she meets. On being introduced to a character called the Advanced Lady, who proclaims, "I think you are English?"” the narrator simply agrees"I acknowledged the fact"20 — thus deflecting attention from the question of her identity. But in "The Luftbad," her anonymity is challenged. Upon being asked by the Vegetable Lady whether she is an Englishwoman or an American, and answering evasively, "Well hardly," she is told, "'You must be one of the two; you cannot help it.",21 This tart response implies a certain German purism about national identity, and wariness of the colonial hybridity that Mansfield/the narrator may embody as a form of cultural difference. ${ }^{22}$ The narrator's questionable assertions made in other stories, that she has been a vegetarian for three years of marriage (in "Germans at Meat"), and her "virgin conception", announced to Frau Fischer - of a husband who is "a sea-captain on a long and perilous voyage" contribute to the impression of unreliability. ${ }^{23}$ Whether her self-inventions and evasions are a self-protective device or part of a self-conscious performance to exploit cultural misunderstanding and misinterpretation for satirical ends, they are a significant source of the structural ambivalence that Andrew Harrison identifies as a cohering principle of the collection. $^{24}$ 
Mansfield's oblique obfuscation through the voice of her narrator by reinventing herself as "other" to her earlier self, however, allowed her to develop a more artistic response to the perceived threat to her hybrid colonial-metropolitanism that the encounter represented. In this context, the Pension Müller can be identified as a cultural contact zone, "a social space where disparate cultures meet, clash, and grapple with each other, often in highly asymmetrical relations of domination and subordination. ${ }^{, 25}$ Like the third space of diaspora or migration promulgated by Homi Bhabha, this is an intercultural, translational zone, neither metropolitan nor colonial, in which Mansfield and her proxy narrator might engage in the politics of identity and difference, involving negotiation and contestation about position and selfhood with the Pension's German residents. Framing these encounters with Bhabha's postcolonial theory of cultural difference, therefore, encourages the perception that the narrator's effacement of her external identity belies the activity of an interior space of subjectivity to formulate private responses to the entrenched and culturally determined beliefs held by the Germans; ${ }^{26}$ this appears in her oscillation between engagement with and withdrawal from their pronouncements and conversations, and in asides about her indifference such as "I did not care one way or another."27

Mansfield's disequilibrium also appears in the inconsistency of her satire on German pretensions and assumptions and uneven deployment of a narrative strategy aimed to engage the readers' sympathy on the one hand while maintaining a critical distance on the other. This stems in part from the narrator's indeterminate role, whether as distanced, observing outsider, objectified stranger, or actively engaged participant. Acting as a foil for stereotypes of Englishness, she reveals German imperialism's sinister intent: Anglo-German tensions prior to World War One are implied by "the cold blues eyes" of Herr Rat, and his "expression which suggested a thousand premeditated invasions." ${ }^{28}$ On domestic topics the German point of view is insidiously mocked; she ironically takes on the "burden" of the "nation's 
preposterous breakfast" described in "Germans at Meat," confiding to readers: "I who drank a cup of coffee while buttoning my blouse in the morning." ${ }^{29}$ Assertions of national deficiency that might threaten her metropolitan identity appear: the English nation is "so unmusical," it avoids discussing bodily functions, and is "“Fish-blooded [...] Without soul, without heart, without grace." ${ }^{30}$ Satire yields to issues of identity in "The Modern Soul" when she is introduced to Frau Godowska and her daughter by Herr Professor, being "othered" as "the stranger in our midst," and told that we "have often observed you through the bedroom window." 31 Yet there is a yearning to belong, as Todd Martin notes, significantly when a symbol of imperial power, the portrait of the Kaiserin Elizabeth, Empress of Austria and Queen of Hungary, is removed from her room in "The Sister of the Baroness," making the narrator feel "outside the pale," and branded "as a foreigner."32 The narrator is both like and unlike the Germans, differentiating herself from characters like Frau Godowska, Frau Fischer, and the Vegetable Lady by her ironic poise, while exhibiting similarities to others who also dissemble; by sharing the same material reality as that of her satirical targets, and surviving by a seeming compliant yet resistant response to their ideology, Mansfield was able to develop a more potentially political subjectivity in her inner space.

The narrator's variable positioning is especially evident in two stories, “The Sister of the Baroness" and "The Baron," whose eponymous characters, mirroring her deceptions and evasions, are literary doubles. Both concern the powerful impact of the German aristocracy as high-ranking figures who can hoodwink or puzzle those around them. They turn on moments of revelation: in "The Sister of the Baroness," her dressmaker's daughter is impersonating the baroness, a fraudster passing herself off as an aristocrat and gaining the adulation of the student from Munich and the poet from Bonn. In "The Baron," the unbaronial-looking Baron, a self-selected outsider, like the fascinated narrator, confesses to her that he hides away to conceal his gross appetite; her unique conversation with him wins her admiration from the 
others who rank social status above all else. Like the more confrontational attitudes of "Germans at Meat," "Frau Fischer," and "In the Luftbad," the atmosphere of suspicion and insinuation in these less overtly satirical stories implicates the reader who cannot completely disidentify from gullible and earnest Germans like Frau Fischer who are being satirized or deceived, whether by the narrator or other characters. Harrison's observation of "an uncanny dynamic" pervading the collection, due to the erratic "strangeness and animosity" of the narrator, ${ }^{33}$ encourages further interpretation of the Pension as an intercultural contact zone, informed by Bhabha's concept of "the uncanny structure of cultural difference" where the familiar yields to the strange, and where collaboration and contestation also occur. Citing Levi Strauss, Bhabha says that "the unconscious" provides "the common specific character of social facts [... I]t enables us to coincide with forms of activity which are both at once ours and other." 34 The narrator's encounter with dominant, metropolitan modes of representation as molded by Bavarian middle-class assumptions is marked by the uneven irruption into the satirical surface of her "angry vibrations," 35 her repressed interpretations and sudden appropriations.

Mansfield, then, can be seen as intermittently struggling to create a counter-imaginary to the Catholic society of early twentieth-century Bavaria in contesting the Pension residents' proclamation of hegemonic imperial attitudes and assumptions which may have seemed "consecrated" and "fossilized." ${ }^{36}$ Her compromises are constituted in the narrator's ambivalent self-representations and enigmatic stance. They may be traced to Mansfield's unease about gender inequality and injustice, reflecting her own trauma at being trapped in a female body: fears of homelessness and isolation, abandonment on becoming pregnant, marital rape, financial dependency on men, and childish rage. A concern with what "the modern" means for women appears in stories such as "The Advanced Lady" and "The Modern Soul," and although not consistently thematized, can be linked to a narrative 
antipathy towards sexuality when privileged as the principle category of consciousness. This is the basis of stories about male sexual drives that highlight women's gendered expectations, sexual naivete, and social conditioning as in "Frau Brechenmacher Attends a Wedding" and “At Lehman's."

The narrator's most explicit attack is reserved for pronouncements revealing the biological essentialism that decrees women as destined for matrimony and motherhood, reflecting the ideology associated with imperial rule that elevates family and childrearing as supreme values. Presented as though unshakeable truths, are Frau Fischer's claims that "every wife ought to feel that her place is by her husband's side," and that "handfuls of babies" will ensure marital stability, because "as the father of a family he cannot leave you"; 37 while the Traveller's assertion, "Germany [...] is the home of the Family," 38 categorically reinforces national pride. Hostility to exploitation of child labour dominates "The-Child-Who-Was-Tired," where it is represented as a form of slavery that leads to murder. The stories focus on the female inability to contest male power, and Mansfield's satire exposes how such transgressive urges have become "naturalised" within empire's heteronormative culture while simultaneously permitting hypocrisy and moral evasion.

One target is the ironically labelled "The Advanced Lady," a writer and intellectual who claims to be a voice of modernity while distancing herself from others in the Pension and neglecting her child and husband. This deeply "unmodern" figure may be a caricature of a European intellectual who was then advancing anti-feminist views under the guise of being modern, namely, the German writer Laura Marholm, whose Studies in the Psychology of Women (1899) Mansfield borrowed from the General Assembly Library in Wellington during 1906-08. According to Sydney Janet Kaplan, Marholm's thesis was that men and women are innately and biologically different, and her full argument, that women's so-called "emancipation" was a displacement of their emotional energies due to the enfeeblement and 
demasculinization of men in a post-industrial "degenerate" age, would have troubled Mansfield. ${ }^{39}$ One similarity between them is that the Advanced Lady claims to be writing a novel "upon the Modern Woman," 40 and Marholm's work opens as if it is a novel. The Advanced Lady's modernist beliefs, however, are misguided, for her pretense at improving women's condition does little more than reinforce the essentialist notion that women are biologically destined agents of reproduction, even as she ignores her own child. She glorifies women's capacity for self-sacrifice saying, “"our gifts of giving are for the whole world—we are the glad sacrifice of ourselves," ${ }^{41}$ provoking the narrator's retaliation " "that theory of yours about women and love—it's as old as the hills—oh, older." ${ }^{42}$ This criticism may reflect modern socialist thinking, for despite her negativity about women's suffrage after attending a suffragist meeting in London in September $1908,{ }^{43}$ Mansfield was of the view, even before she left New Zealand, that women "truly, as yet, have never had their chance. Talk of our enlightened days and emancipated country. Pure nonsense." ${ }^{44}$

More savage portraits can be traced to Mansfield's social outrage at abuses of power and the exploitation of vulnerable children and women, as in the Chekhovian story, "TheChild-Who-Was-Tired," in which a very young girl laboring under impossibly harsh conditions smothers the baby in her care in order to find release. A trenchant critique of masculine power and imprisoning attitudes towards women — offering a more sinister angle on the Advanced Lady's advocacy of female sacrifice and willing victimhood-appears in "Frau Brechenmacher Attends a Wedding." Frau Brechenmacher's unspoken fears of her husband's sexual power, manifested in frightened domestic subservience and psychological dependence, and transferred to her oldest daughter, create a female cycle of oppression. ${ }^{45}$ Herr Brechenmacher's monstrous sexual appetites are registered in the underlying violence with which he exerts control over the drunken, raucous wedding celebration; while the silence due to inarticulate fear contribute to a symbolic portrayal of Frau Brechenmacher and 
the other female guests as "dumb in their captivity under bestial sexual norms." reinforced in Frau Brechenmacher's final gesture when she "lay down on the bed and put her arm across her face like a child who expected to be hurt as Herr Brechenmacher lurched in. $" 47$

Mansfield's preoccupation with issues of gender inequality, and by implication with entrenched Catholic values concerning women's maternal and domestic roles that she encountered in the Pension Müller, has a symbolic counterpart in the complex linguistic makeup of the stories; her narrators and characters constantly engage in acts of cultural translation and linguistic border crossings, and their in-between positioning in the space of translation that is the Pension is reflected in the cultural hybridity of the narratives. Communication is marked by discontinuity and rupture; sudden sounds and monosyllabic utterances represent moments of crisis or confusion. For example, "Ach,” an exclamation with a negative emphasis, is repeated seven times throughout the stories, but the louder shriek "achk," in "At Lehman's" from the sexually innocent Sabina when the Young Man touches her breasts reflects a more enigmatic disturbance. ${ }^{48}$ The awkwardness of some translations indicate the struggles to communicate effectively in this multi-lingual zone. Herr Rat, for example, talks of taking a "knee bath" and "an arm bath" while untranslated words contribute to erratic, halting exchanges. The day's "kur" ("cure") is the subject of intense discussion in "The Baron," while in "Germans at Meat" the untranslated terms "magen" ("stomach") and "Mahlzeit" ("Enjoy your meal”) appear, but the narrator's struggle for the German equivalent for "the preliminary canter" in trying to explain "warming the teapot," ends in silence. ${ }^{49}$ Linguistic instability due to being in a translational space pervades the stories; in the process of translation words as signifiers become untethered from their signifieds, and linguistic slippages point to incomplete or disrupted communication. This sense of the unreliability of 
language, the mixing of linguistic registers and fusion of different codes, symbolically disturbs the inward-looking monocultural, monolingual monopoly of the German speakers, and adds to the effects of strangeness and uncanniness that can be discerned below the linguistic surface and the narrator's superficial familiarity.

The disjunctive communication between the narrator and her German interlocutors culminates in a performative gesture when she abruptly walks away from the Vegetable Lady's interrogation in "The Luftbad." Flying into the air on a swing, she defies the earthly circle below, elated by the animating flows of wind, the scent from the pine trees, and rhythmical movements of the branches; this becomes an ecstatic moment of fusion, of oceanic belonging:

I got up and climbed onto the swing. The air was sweet and cool, rushing past my body. Above white clouds trailed delicately through the blue sky. From the pine forests streamed a wild perfume, the branches swayed together rhythmically, sonorously. I felt so light, and free and happy—so childish! I wanted to poke my tongue out at the circle on the grass who, drawing close together, were whispering meaningfully. ${ }^{50}$

As an early epiphany in Mansfield's fiction, this is unusual for its refusal to collapse inward, although it also resists transcendence; ${ }^{51}$ it remains an image of abandonment and rebellion through the narrator's elevation — literally and metaphorically_-from the pedestrian mind-set and inconsequential chatter of the women. This might be an "outlaw" moment, according to Fullbrook, based on the narrator's insight into a discrepancy between this self-perception and previous ones, and her discovery of previously unrecognized elements of consciousness, so setting her apart. ${ }^{52}$ But in fact, the narrator's seeming dissolution of self into the elements in a 
Freudian oceanic moment and her infantile swinging and desire to poke her tongue out suggest a detachment from the realm of language and a reversion to a pre-oedipal symbolic order through a loss of sovereignty or control. This may be associated with Bhabha's view that in the border zones of diasporas such as the third space, in the context of transcultural negotiation, the non-sovereign self is needed in order to articulate difference and to live with it, for "it is only by losing the sovereignty of the self that you can gain the freedom of politics that is open to the non-assimilationist claim of cultural difference." ${ }^{, 53}$ Such seeming detachment from the value system of the Germans suggests a new model by which to articulate foreignness and strangeness emerging from Mansfield's/the narrator's incomplete or inauthentic reconfigurings of her earlier narratives of origin and subjectivity. That is, the different forms of cultural and linguistic hybridity in the stories associated with the third space - the mocking of hierarchies implied by aristocratic titles, the blends of languages and speech codes, and the tropes of doubling and mirroring implicit in the narrator's masks and duplicity - all imply an undermining of the German values of Aryanism, genetic purity, cultural superiority, and racial whiteness, and Mansfield's search for a consolidated position from which to recuperate her threatened cosmopolitanism and approach an alternative ideology that, as these stories show, demands constant cross-cultural, self-other negotiation.

Although attitudes associated with empire — such as white racial power, linguistic and cultural supremacy — can be traced in Mansfield's sarcastic comments on German spa life, these explorations of social and national identities that hint at incomplete or unknown individual subjectivities and the concealment of cruelty, injustice, and domestic oppression suggest a non-partisan distance from the powerful structure of German military imperialism. ${ }^{54}$ The wave of anti-German feeling that swept Britain in 1910 is alluded to in "Germans at Meat" by the Traveller in his comment on the English fear of an invasion and the play staged in London that fanned this fear, ${ }^{55}$ and Mansfield, when writing up the stories 
in London that year, was evidently aware of the growing militancy about the threat the Germans posed to England's sense of its empire. Despite elements of critique implied by the hybridized doubled position of the satirical narrator, her narrative tactics can only be read indirectly as a challenge to imperial values. ${ }^{56}$ Mansfield's caricature of Germans and lampooning of individual and institutional stereotypes were held in check partly by her ambivalence towards European politics at a time when tensions were building up to the outbreak of the First World War in $1914 .{ }^{57}$ Nevertheless the Pension stories occupy a pivotal place in her artistic evolution, for they show her responses to imperial cultural supremacy obliquely linked to assertions of German superiority and military power being made then, and which she explored in the domestic sphere through culturally specific narratives about sexual dominance and compliance.

\section{"The Woman at the Store" and "Millie"}

Mansfield's counter-imaginary to the imperial orientation of the Pension stories takes shape in two New Zealand stories, "The Woman at the Store" and "Millie," published in Rhythm in 1912 and the Blue Review in 1913. They are set in outback New Zealand on the edges of empire, a lawless zone where savage, primitive urges involve sex crimes and murder. A reading of them as oppositional to those anchored in the gemütlich, well-ordered world of the Pension with its rules, regulations, and wholesome, life-building regime of diet, exercise, and cold baths suggests that the norms of gender, marriage, and childbirth associated with empire, when transported to the unruly, unpredictable colonial setting, become deformed and inverted; both signal the collapse of the imperial ideology that elevates these stabilizing domestic values. The domestic violence in stories like "Frau Brechenmacher Attends a Wedding," child abuse in "The Child Who Was Tired," and the ambivalent sexual gropings in "At Lehman's" are revisited in images of denatured womanhood, the consequence, it is 
implied, of an over-masculinized society in which indifference, brutality, and violence underlie relationships. Satire is now reconfigured in terms of the colonial Gothic in forms of ghostly disturbances, abnormal climatic and environmental conditions, sensations of terror, and threats of the unexpected, all associated with gender instability. The social conventions and formal politeness of the German society of Wörishofen are stripped away as Mansfield develops her response to the aesthetic of the primitive and brutal associated with the manifesto of Rhythm in these narratives of imperial and colonial barbarism. "The types of ab/normality cross over each other chiastically, marked by more insistent rhythms of savagery in the colony. They will surface most monstrously in that ultimate deformation, the Great War where they are played out on a world stage." 58

Both stories draw on the colonial narrative phenotype, as Lydia Wevers points out, ${ }^{59}$ such as the yarn or the tale associated with the Bulletin "horse and saddle" genre or Barbara Baynton's bush studies, while "The Woman at the Store" shows thematic and narrative affinities with Henry Lawson's short story “The Drover's Wife”; however, their images of gender instability can also be traced to the disturbing attitudes of Pension characters, such as the Advanced Lady who attacks "those violent creatures who deny their sex." ${ }^{60}$ Gender inversion and sexual transgression due to cultural and social isolation in the colony are associated with violent, fatal retaliation. In "The Woman at the Store," the abject, violated woman who, it is rumored among the three travelers, knows 125 "different ways of kissing," 61 is revealed as a murderer, having killed her husband who has brutalized her. Symbolically outside the bounds of civil society, as a non-woman, her radical dehumanization is suggested by the narrator's comparisons of her to a puppet or "wax doll," as "nothing but sticks and wires under that pinafore," 62 and by her aggressively phallic gesticulations with the gun and threat to the child if she dare expose her secret. The denatured, masculinized, eponymous Millie, also armed with a gun, epitomizes the menacing 
spirit of an environment which leaves little room for women's reproduction, tenderness, or maternal instincts. Wondering at her lack of fertility, Millie naturalizes her barrenness, saying “"I've never missed them,"” implying that her husband Sid who is "softer" might have. ${ }^{63}$ In these ambivalent characters, the "lying garb of false masculinity" that the Advanced Lady denounces, ${ }^{64}$ is resurrected as a necessary truth because a fact of harsh colonial habitation.

These isolated figures have associations with but with no real knowledge of their originary homeland of the British empire. Jameson says of these colonial dislocations that the colonial subject is "unable to register the peculiar transformations of the first world, or metropolitan life which accompany the imperial relationship." ${ }^{\circ 5}$ Mansfield marks out the colony's distance from its mother-culture with iconic symbols of imperial and national authority that signify colonial "belonging" (so counterpointing the narrator's feelings of exclusion when the portrait of Kaiserin Elisabeth is taken from her room in "The Sister of the Baronness"). In "Millie," the painting of Windsor Castle with "three Union Jacks" and "the old queen" causes Millie to ask, "“I wonder if it really looked like that?" before turning to the photograph of her wedding day with its national landscape signifiers: "fern trees, waterfall and Mount Cook." 66 "The Woman at the Store" also contrasts the colony/empire dyad: an English periodical featuring Queen Victoria's jubilee in the room behind the store is adjacent to "a coloured print of Richard Seddon," ${ }^{67}$ New Zealand's Liberal Prime Minister until his death in 1906, above the mantelpiece.

Both narratives begin in the dismantling of opposites. The moral and social hierarchy of empire and colony is reversed in "Millie", where it is the newly-arrived English "johnny," a farm laborer, who is on the run and whose youth, vulnerability, and terror arouse Millie's maternal feelings as she reaches out to comfort him as the child she never had. Heteronormative gender relations associated with imperial rule are further undermined by an 
off-stage contretemps, in what is implied is a queer relationship between the Englishman and Mr. Williamson, whom Millie recalls as "such a one for a joke. Always having a lark." 68 Only an external perspective, hors de texte, informs us that Millie's naïve curiosity about the motive for the murder would be at odds with the usual suspicions that such relationships arouse.

The narrative of "The Woman at the Store," by contrast, is manipulated by a narrator who oscillates between masculine and feminine traits, at first appearing as a male traveler in the company of two others, and then revealed as a woman in a vulnerable state of nudity by the woman's six-year-old daughter who claims she saw her sunbathing after swimming in the creek. This wandering, sexually ambivalent figure resembles Mansfield's metropolitan/colonial identity and ability to negotiate the psychological and cultural differences between colony and empire. Speaking as a cosmopolitan traveler, she denigrates the menacing situation and deformed characters - "the hideous room, the rat of a child, the mangy dog" ${ }^{\prime 2}$ — recoiling from empathy or pity as might be proffered by one woman to another, and hinting at masculine abhorrence: the woman is " ugly [...] a figure of fun $[\ldots]$ mad" and the child's drawings is "repulsively vulgar $[\ldots]$ the creations of a lunatic."

In "Millie," the biological drives of maternal affection resurface with the force of the repressed when Millie empathizes with the hunted man's fear, but in the story's conclusion, her abrupt reversal and rejection of him leads her to identify with her husband and the posse that pursue him. Like the narrator's antipathy to the woman and child in "The Woman at the Store," which suggests fear of contamination and an attempt to maintain a moral and physical distance, Millie's part in the fate of the young boy is symbolically that of a mediating or threshold figure, as defined by Anne McClintock, demarcating a boundary between empire and the colonized world. ${ }^{71}$ In each case is a realization that the abject "other" must be refused despite suggestions that the self-other relationship is simultaneously transformative and 
destabilizing. Both narratives mark a temporary reprise from the status quo: Millie can only reclaim her subjectivity by restoring her masculinized defeminized self; the woman in "The Woman at the Store" can only recover her previous self by attempting to seduce Jo, one of the three travelers.

Mansfield's Bavarian sojourn in the heart of the German empire as recorded in the stories of In a German Pension inspired her to return to the colonial world intent on exposing the paradox of the colonial subject being "othered" in stories about domestic violence. Like one of those "neobarbarians" espoused by Frederic Goodyear in Rhythm, she was writing to "familiarise us with our outcast selves." 72 She does so by creating what Elyse Blankley defines as a "queered space" for the narrator in "The Woman at the Store" immune from the degradation described, she can imply a challenge to gender narratives central to the British Empire's self-representation through a nascent counter-narrative: an ambivalent metropolitan-colonial worldview that exposes gender transgressions and violations without the protective hypocrisies of Victorian morality. In "Millie," a similar queered space can be glimpsed beyond the borders of the text in the strange relationship between the colonial Mr. Williams and the English johnny. Its "barbaric" outcome paradoxically enables Millie's unexpected discovery of her essential female side, while remaining oblivious to the prohibition that ostracizes and condemns so-called indecent sexual practices. The unspoken question of sympathy toward such oppressed relationships amidst likely homophobic revulsion ironizes her final words. " $\mathrm{A}-\mathrm{ah}$ ! Arter 'im, Sid! $\mathrm{A}-\mathrm{a}-\mathrm{a}-\mathrm{h}$ ! Ketch him, Willie. Go it! Go it! A—ah, Sid! Shoot 'im down. Shoot 'im!"’74 As Blankley points out, these aporias and gaps which encourage a forensic deductive reading, both expose yet veil the crimes that signal the collapse of imperialist domestic impulses.

Mansfield's early writing is inspired by the insight that domestic violation and transgression occur both in the imperial metropolitan centers and the colonies. But in her 
colonial stories she developed a colonial-modernist angle in the critique of empire which is buried beneath the satirical gaze of the Pension stories, manipulating the structural principles of ambivalence, masking, and insinuation to indicate the depths of criminality that underlie the domestic world of the colony. In advancing from the "foreign" present to reinterpret the "familiar" past she inscribes a metropolitan dimension into her colonial narratives of savagery, exploring the opposition between the imperial "cooked" and colonial "raw" categories (to adapt Levi-Strauss's terms of mythological structures), transforming them through irony and queerness. Finally, in hinting at textual gaps and ellipses from which alternative subjectivities and resistances will be opened up, her endeavor recalls another modernist axiom, "to see that the present is pregnant of the future, rather than a revolt against the past"; 75 these experimental stories anticipate later critiques like "Je ne parle pas français" and "The Daughters of the Late Colonel," as well as the discourses to come of later postcolonial writers and critics.

\section{Notes}

${ }^{1}$ See Lydia Wevers, “"The Sod Under my Feet': Katherine Mansfield,” in Opening the Book: New Essays on New Zealand Writing, ed. Mark Williams and Michelle Leggott (Auckland: Auckland University Press, 1995), 31-48; "How Kathleen Beauchamp was Kidnapped," in Critical Essays on Katherine Mansfield, ed. Rhoda B. Nathan (New York: G. H. Hall \& Co, 1993), 37-47; Bridget Orr, "Katherine Mansfield, Colonial Modernist," in A History of New Zealand Literature, ed. Mark Williams (Cambridge: Cambridge University Press, 2016), 7181. 
${ }^{2}$ See Janet Wilson, “Introduction,” Katherine Mansfield and the (Post)colonial, eds. Janet Wilson, Gerri Kimber, and Delia da Sousa Correa. Katherine Mansfield Studies 5 (Edinburgh University Press, 2013), 1-14; Elleke Boehmer, "Mansfield as Colonial Modernist; Difference within," in Celebrating Katherine Mansfield, ed. Gerri Kimber and Janet Wilson (Houndmills, Basingstoke, Hampshire: Palgrave, 2011), 57-71; Saikat Majumdar, Prose of the World: Modernism and the Banality of Empire (New York: Colombia University Press 2013); Elyse Blankley, “Gendered Violence and Narrative Complicity in Katherine Mansfield and Leonard Woolf," (paper presentation, Katherine Mansfield: Inspirations and Influences, Jagiellonian University, Krakow, Poland, July 2019). I am grateful to her for allowing me to read a copy of her paper.

${ }^{3}$ See Gaurav Majumdar, “Marking Absence: Mansfield's Feminine Informality vs. Lockean Liberalism.” In Katherine Mansfield 2020, edited by Aimee Gasston, Gerri Kimber and Janet Wilson. Special issue of Journal of New Zealand Literature. Forthcoming 2020.

${ }^{4}$ Jed Esty, Modernism and National Culture in England (Princeton NJ: Princeton University Press, 2003), 30 .

${ }^{5}$ See Mark Williams, "Mansfield in Maoriland: biculturalism, agency and misreading," in Modernism and Empire, eds. Howard J. Booth and Nigel Rigby (Manchester and New York: Manchester University Press, 2000), 249-74; Modernism and Colonialism: British and Irish Literature, 1899-1939, eds. Richard Begum and Michael Valdez Moses (Durham and London: Duke University Press, 2007); Elleke Boehmer, Empire, the National and the Postcolonial 1890-1920 (Oxford: Oxford University Press, 2002).

${ }^{6}$ James Clifford, The Predicament of Culture: Twentieth Century Ethnography, Literature, and Art (Cambridge, MA: Harvard University Press, 1988), 3-4.

${ }^{7}$ Boehmer, Empire, the National and the Postcolonial, 4. 
${ }^{8}$ Fredric Jameson, "Modernism and Imperialism," in Nationalism, Colonialism, and Literature, eds. Terry Eagleton, Fredric Jameson, and Edward Said (Minneapolis MN: University of Minnesota Press, 1990), 48.

${ }^{9}$ Simon During, "Katherine Mansfield's World,” Journal of New Zealand Literature 33 (2015): 49 .

${ }^{10}$ Boehmer, Empire, the National and the Postcolonial, 174; Orr, "Colonial Modernist," 72.

${ }^{11}$ Declan Kiberd, "Postcolonial Modernism," in Modernism and Colonialism: British and Irish Literature, 269-87; Williams, "Mansfield in Maoriland,” 255-60; Jane Stafford and Mark Williams, Maoriland: New Zealand Literature 1872-1914 (Wellington: Victoria University Press, 2006), 157.

12 [John Middleton Murry and Katherine Mansfield], “Aims and Ideals,” Rhythm 1, no. 1 (1911): 36 .

${ }^{13}$ Letters 3, 82.

${ }^{14}$ Galya Diment, "Introduction," in Katherine Mansfield and Russia, ed. Galya Diment, Gerri Kimber, and Todd Martin (Edinburgh: Edinburgh University Press, 2017), 2.

${ }^{15}$ Ato Quayson, "Introduction: Changing Contexts of the Postcolonial Novel," in The Cambridge Companion to the Postcolonial Novel, ed. Ato Quayson (Cambridge: Cambridge University Press 2016), 3.

${ }^{16}$ Henceforth "Wörishoften," as the town was known in 1909; "Bad" was conferred on 6 March 1920 by a decree issued by the Bavarian State Ministry of the Interior.

${ }^{17}$ It is not known whether her mother, Annie Beauchamp, knew Mansfield was pregnant. Almost all of Mansfield's letters from this period were destroyed, and her diary entries are minimal.

${ }^{18}$ Letters $1,92$. 
${ }^{19}$ Ibid.

${ }^{20} \mathrm{CW} 1,236$.

${ }^{21}$ Ibid., 177.

${ }^{22}$ See Todd Martin, “'Unpacking’ the First-Person Narrator of In a German Pension,” in Katherine Mansfield and the (Post)colonial, 81. This conflation of colonial and “imperial"/metropolitan subjects suggests the limited recognition of New Zealanders in Europe then. The New Zealand accent was first noticed among schoolchildren only in 191112, after Mansfield had left. See Elizabeth Gordon and Tony Deverson, New Zealand English: An Introduction to New Zealand Speech and Usage (Auckland: Heineman, 1985), $15-17$.

${ }^{23} \mathrm{CW} 1,198 ; 197$.

${ }^{24}$ Andrew Harrison, “Ambivalence, Language and the Uncanny in Katherine Mansfield's In a German Pension," Katherine Mansfield Studies 4 (2012): 51-2. Harrison frames his observation in terms of the Freudian uncanny.

${ }^{25}$ Mary Louise Pratt, Imperial Eyes: Travel Writing and Transculturation, 2nd ed. (London and New York: Routledge, 2008), 7-8.

${ }^{26}$ See Homi Bhabha, The Location of Culture (Routledge: London and New York, 1994).

${ }^{27}$ CW1, 195-96.

${ }^{28}$ Ibid., 165.

${ }^{29}$ Ibid.

${ }^{30}$ Ibid., 195; 216.

${ }^{31}$ Ibid., 215; 216. The historical spelling is Elisabeth. Kaiserin is the wife of a Kaiser or king in Germany, but in Austria, as the wife of Franz Joseph I, Emperor of Austria and King of 
Hungary, Elizabeth's title was Empress. ${ }^{32}$ Martin, “'Unpacking' the First-Person Narrator,” 83; CW1, 190.

${ }^{33}$ Harrison, “Ambivalence, Language and the Uncanny," 54.

${ }^{34}$ Bhabha, The Location of Culture, 163. Emphasis in original.

${ }^{35} \mathrm{CW} 1,240$.

${ }^{36}$ Esty, Modernism and National Culture, 26, citing Perry Anderson on imperialism as a force of traditionalism in culture, English Questions (London: Verso, 1992), 24.

${ }^{37}$ CW1, 197; 198.

${ }^{38}$ Ibid., 166.

${ }^{39}$ Sydney Janet Kaplan, Katherine Mansfield and the Origins of Modernist Fiction (Ithaca and London; Cornell University Press, 1991), 133-34.

${ }^{40} \mathrm{CW} 1,239$.

${ }^{41}$ Ibid., 240.

42 Ibid., 241.

${ }^{43}$ Letters 1, 59-61. In Katherine Mansfield and the Origins of Modernist Fiction, Kaplan points out that she acknowledged other aspects of oppression, such as victimization, rape, venereal disease, and various types of dependence (127-9).

${ }^{44}$ CW4, 91.

${ }^{45}$ Fullbrook, Katherine Mansfield (Brighton: The Harvester Press Ltd, 1986), 54.

${ }^{46}$ Ibid., 56.

${ }^{47} \mathrm{CW} 1,189$.

${ }^{48}$ See Harrison, “Ambivalence, Language and the Uncanny," 59-60; Fullbrook, Katherine Mansfield, 57-58.

${ }^{49} \mathrm{CW} 1,164 ; 167 ; 165$. 
${ }^{50}$ Ibid., 177.

${ }^{51}$ During, "Katherine Mansfield's World," 45-6. ${ }^{52}$ Fullbrook, Katherine Mansfield, 32.

${ }^{53}$ Homi Bhabha, “The Third Space,” Interview with Jonathan Rutherford, in Identity:

Community, Culture, Difference (London: Lawrence \& Wishart Ltd, 1990), 212.

${ }^{54}$ Martin, “'Unpacking' the First-Person Narrator,” 77, citing Lee Garver, "The Political

Katherine Mansfield," Modernism/Modernity 8, no. 2 (2001): 228.

${ }^{55}$ The play is identified as Guy du Maurier's An Englishman's Home, CW1, 168n3.; Martin, “"Unpacking' the First-Person Narrator,” 78.

${ }^{56}$ This may explain why later in life she refused to have the stories reprinted. See Fullbrook, Katherine Mansfield, 52-53.

${ }^{57}$ Martin points out that New Zealand did not display anti-Germanic sentiments before the war. See Martin, “"Unpacking' the First-Person Narrator,” 80.

${ }^{58}$ An email comment made by Anna Smith. I would like to thank her for reading a draft of this chapter and suggesting the chiastic metaphor.

${ }^{59}$ Lydia Wevers, "Katherine Mansfield is the Problem," in Teaching Australian and New Zealand Literature, eds. Nichola Birns, Nicole Moore, and Sarah Shieff (New York: Modern Language Association, 2017), 91.

${ }^{60} \mathrm{CW} 1,239$.

${ }^{61}$ Ibid., 272.

${ }^{62}$ Ibid., 270.

${ }^{63}$ Ibid., 327.

${ }^{64}$ Ibid., 239.

${ }^{65}$ Jameson, "Modernism and Imperialism," 60. 
${ }^{66} \mathrm{CW} 1,327$.

${ }^{67}$ Ibid., 270.

${ }^{68}$ Ibid., 327.

${ }^{69}$ Ibid., 271.

${ }^{70}$ Ibid., 271; 274.

${ }^{71}$ Blankley, "Gendered Violence and Narrative Complicity," n. p., citing Anne McClintock Imperial Leather: Race, Gender and Sexuality in the Colonial Context (Abingdon and New York: Routledge, 1995), 24.

${ }^{72}$ Frederick Goodyear, “The New Thelema,” Rhythm 1, no.1 (1911): 3.

${ }^{73}$ Blankley, "Gendered Violence and Narrative Complicity," n. p.

${ }^{74} \mathrm{CW} 1,330$.

75 [Murry and Mansfield], “Aims and Ideals,” 36. 